\title{
Determination Of Base-Flow Characteristics At Selected Streamflow-Gaging Stations ON The Mad River, OHio
}

By G.F. Koltun

U.S. GEOLOGICAL SURVEY

Water-Resources Investigations Report 95-4037

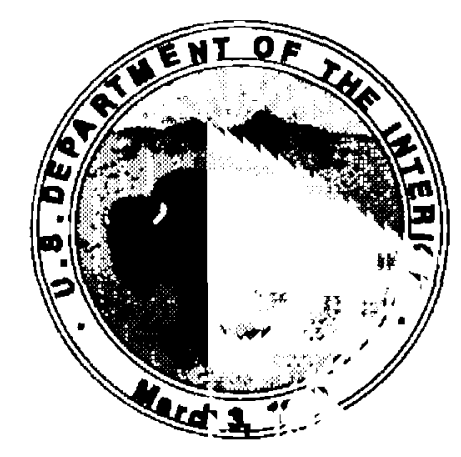

Prepared in cooperation with the OHIO DEPARTMENT OF NATURAL RESOURCES, DIVISION OF WATER 


\section{U.S. DEPARTMENT OF THE INTERIOR \\ BRUCE BABBITT, Secretary \\ U.S. GEOLOGICAL SURVEY \\ Gordon P. Eaton, Director}

For additional information write to:

District Chief

U.S. Geological Survey

975 W. Third Ave

Columbus, Ohio 43212-3192
Copies of this report can be purchased from:

U.S. Geological Survey

Earth Science Information Center

Open-File Reports Section

Box 25286, Mail Stop 517

Denver Federal Center

Denver, CO 80225-0425 


\section{CONTENTS}

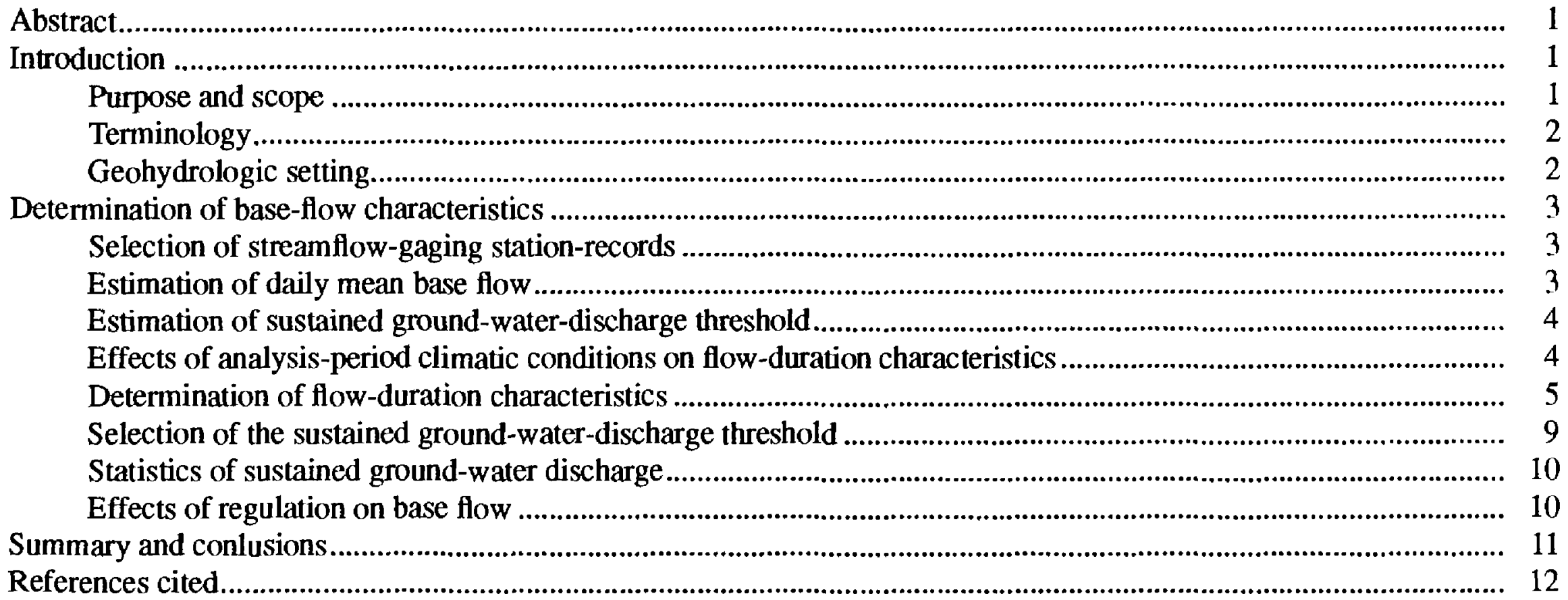

\section{FIGURES}

1. Location map showing study area

2. Annual departure from mean annual-mean discharge for water years 1915-92 at the Mad River near Springfield, Ohio.

3. Streamflow and base-flow duration curves for the Mad River at Zanesfield, Ohio........................................................ 6

4. Streamflow and base-flow duration curves for the Mad River near Urbana, Ohio .................................................... 6

5. Streamflow and base-flow duration curves for the Mad River at St. Paris Pike (at Eagle City), Ohio ..................... 7

6. Streamflow and base-flow duration curves for the Mad River near Springfield, Ohio ............................................. 7

7. Streamflow and base-flow duration curves for the Mad River near Dayton, Ohio .................................................. 8

8. Base-flow duration curve showing selection of sustained ground-water-discharge threshold ................................... 10

\section{TABLES}

1. Hydrologic and sustained ground-water-discharge data for selected sites on the Mad River, Ohio...................... 3

2. Selected base-flow statistics for streamflow-gaging stations on the Mad River, Ohio ........................................... 4

3. Daily streamflow duration characteristics for streamflow-gaging stations on the Mad River, Ohio ...................... 8

4. Daily base-flow duration characteristics for streamflow-gaging stations on the Mad River, Ohio ........................ 9

5. Statistics of sustained ground-water discharges for streamflow-gaging stations on the Mad River, Ohio ............. 9

6. Selected relations between base flows characterized as sustained ground-water discharge and streamflows occurring on the same day. 
CONVERSION FACTORS

\begin{tabular}{rcl}
\hline Multiply & By & To obtaln \\
\hline foot $(\mathrm{ft})$ & 0.3048 & meter \\
mile $(\mathrm{mi})$ & 1.609 & kilometer \\
inch $(\mathrm{in})$. & 25.4 & millimeter \\
cubic foot per second $\left(\mathrm{ft}^{3} / \mathrm{s}\right)$ & 0.02832 & cubic meter per second \\
square mile $\left(\mathrm{mi}^{2}\right)$ & 2.590 & square kilometer \\
\hline
\end{tabular}

Temperatue can be converted to degrees Celsius $\left({ }^{\circ} \mathrm{C}\right)$ or degrees Fahrenheit $\left({ }^{\circ} \mathrm{F}\right)$ by the equations:

$$
\begin{aligned}
& { }^{\circ} \mathrm{C}=5 / 9\left({ }^{\circ} \mathrm{F}-32\right) \\
& { }^{\circ} \mathrm{F}=9 / 5\left({ }^{\circ} \mathrm{C}\right)+32 .
\end{aligned}
$$




\title{
Determination of base-flow characteristics at selected streamflow-gaging stations on the Mad River, Ohio
}

\author{
By G. F. Koltun
}

\section{Abstract}

This report describes the results of a study to estimate characteristics of base flow and sustained ground-water discharge at five streamflowgaging stations on the Mad River in Ohio. The five streamflow-gaging stations are located at Zanesfield, near Urbana, at St. Paris Pike (at Eagle City), near Springfield, and near Dayton.

The median of the annual-mean base flows, determined by means of hydrograph separation, ranged from $0.64\left(\mathrm{ft}^{3} / \mathrm{s}\right.$ ) $/ \mathrm{mi}^{2}$ (cubic feet per second per square mile) at Zanesfield to $0.74\left(\mathrm{ft}^{3} / \mathrm{s}\right) / \mathrm{mi}^{2}$ at St. Paris Pike. The median percentage of annual total streamflow attributed to base flow ranged from 61.8 percent at Zanesfield to 76.1 percent near Urbana.

Estimates of an upper limit (or threshold) at which base flows can be considered to be composed predominately of sustained ground-water discharge were made by constructing and analyzing base-flow-duration curves. The sustained ground-water discharges (base flows less than or equal to the estimated sustained ground-waterdischarge thresholds) are assumed to originate from ground-water-flow systems that are minimally affected by seasonal climatic changes. The median sustained ground-water discharge ranged from $0.11\left(\mathrm{ft}^{3} / \mathrm{s}\right) / \mathrm{mi}^{2}$ at Zanesfield to $0.26\left(\mathrm{ft}^{3} / \mathrm{s}\right) / \mathrm{mi}^{2}$ at St. Paris Pike (at Eagle City) and near Springfield. The median sustained ground-water discharge, expressed as a percentage of the median annual-mean base flow, ranged from 17.2 percent at Zanesfield to 38.6 percent near Springfield.

\section{INTRODUCTION}

Streamflow in Ohio's Mad River has long 1 sen recognized as having an unusually large base-flow (ground-water discharge) component (Leverett, 1902). As a consequence, any attempt to understand the overall discharge or transport characteristics of the Mad River requires a good understanding of its baseflow characteristics and their relation to the total streamflow.

Base flow can originate from a combination of local, intermediate, and regional ground-water flc'v systems within an aquifer system. Sustained groundwater discharge (discharge to streams from deep, stable regional and possibly intermediate ground-water flow systems) is affected minimally by seasonal climatic changes and consequently is of particular interest $t$ ) the water resources community.

\section{Purpose and Scope}

This report presents the results of a study tc (1) provide quantitative information on the contribution of surface runoff and base flow to gnoss streamflow at selected streamflow-gaging stations on the Mad River, (2) develop flow-duration curves for the base flow component, (3) estimate the discharge below which the base flow can be considered to $b$ ? composed primarily of sustained ground-water discharge, and (4) determine summary statistics of the sustained ground-water discharges. 


\section{Terminology}

An aquifer is a geologic formation that contains sufficient saturated permeable material to yield significant quantities of water to wells and springs (Lohman and others, 1972). An aquifer can be composed of local, intermediate, and regional groundwater-flow systems. These flow systems are differentiated primarily based on the proximity of the recharge areas to the discharge areas. In a local system of ground-water flow, recharge and discharge areas are adjacent to each other. In an intermediate flow system, recharge and discharge areas are separated by one or more topographic highs or lows. In a regional system, recharge areas are along ground-water divides, and discharge areas lie at the bottom of drainage basins (Toth, 1963).

Base flow is the component of streamflow originating from ground-water discharge (Todd, 1980). Ground-water discharge refers to discharge to streams from a combination of local, intermediate, and regional ground-water-flow systems. In the context of this report, base flow is synonymous with the terms ground-water runoff (Todd, 1980) and effective recharge (Rutledge, 1991).

Sustained ground-water discharge refers to discharge to streams from deep, stable regional and possibly intermediate ground-water-flow systems; that is, ground-water-flow systems that are affected minimally by seasonal climatic changes (Eberts, in press).

Bank storage refers to the variable amount of water stored in the stream banks during stage fluctuations (Singh, 1968).

A flow-duration curve is a cumulative frequency curve that shows the percent of time specified discharges were equaled or exceeded during a given period (Searcy, 1959).

Hydrograph separation is the decomposition of streamflow into components of surface runoff and base flow.

A water year is a continuous 12 -month period selected to present data relative to hydrologic or meteorologic phenomena during which a complete annual hydrograph cycle normally occurs (Paulson and others, 1991). The water year used by the U.S. Geological Survey (USGS) runs from October 1 through September 30, and is designated by the calendar year in which it ends.

\section{Geohydrologic Setting}

The Mad River is located in west-central Ohio and drains approximately $656 \mathrm{mi}^{2}$ (fig. 1). Its headwaters are in Logan County and it flows south and west through Champaign, Clark, and Greene Counties to its confluence with the Great Miami River in Montgomery County. Average annual precipitation in the Mad River basin ranges from about 35 to 38 in. with average annual temperatures ranging from about 51 to $53^{\circ} \mathrm{F}$ (Harstine, 1991).

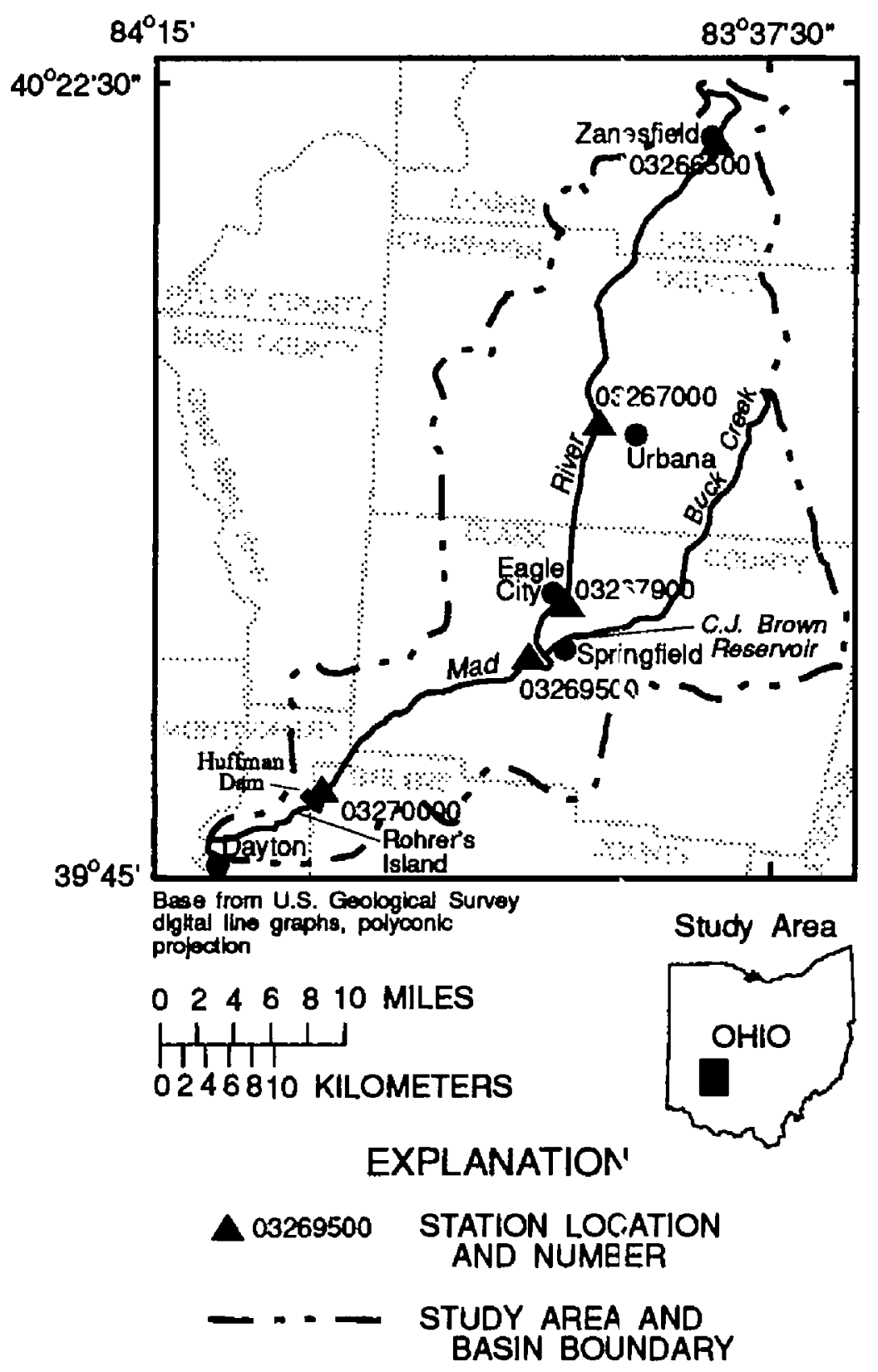

Flgure 1. Location map showing study' area.

The Mad River occupies a broad trough-like valley of preglacial and interglacial oricin with most of its course lying between morainal ridges deposited by the Miami and Scioto lobes of the Wisconsin glacier (Cross and Hedges, 1959). The valley fill consists largely of permeable sand and gravel d posited as kames, kame terraces, high-level outwash, and valleytrain deposits (Cross and Feulner, 1964). The valley fill 
is constricted by bedrock gorges in the vicinity of the city of Springfield and near the boundary between Greene and Montgomery Counties (at Huffman Dam). The gorge through which the stream passes at Springfield is cut in limestone whereas the gorge at Huffman Dam cuts through limestone and shale. Both gorges have relatively impermeable bedrock walls (Cross and Feulner, 1964).

\section{DETERMINATION OF BASE-FLOW CHARACTERISTICS}

\section{Selectlon of Streamflow-Gaglng-Station Records}

Records from streamflow-gaging stations on the Mad River were selected for analysis based on the following criteria: (1) the gaging station must have at least 10 years of daily streamflow record, (2) streamflow during low-flow periods must not be appreciably affected by regulation, and (3) the time period analyzed must span both wet and dry periods. Five streamflow-gaging stations (listed in Table 1) met these criteria.

\section{Estlmation of Dally Mean Base Flow}

The USGS computer program HYSEP (Sloto, 1988) was used to estimate daily mean base flows at the five Mad River streamflow-gaging stations listed in table 1. HYSEP is an implementation of hydrographseparation algorithms originally developed by Pettyjohn and Henning (1979) for use on Ohio streams.

The local-minimum method of hydrograph separation was chosen for this study because it provides the lowest (most conservative) daily mean base-flow estimate of the hydrograph-separation algorithms implemented in HYSEP. In the localminimum method, the lowest discharge value (the local minimum) is determined for a fixed-length time interval. The position of the center of the interval is then incremented 1 day and the local minimum is determined again. This process is repeated until the time period being analyzed has been exhausted.
Discharge values are then calculated between each local minimum by linear interpolation.

Table 1. Hydrologic and sustained ground-waterdischarge data for selected streamflow-gaaning stations on the Mad River, Ohio $\left[\mathrm{t}^{3} / \mathrm{s}\right.$, cubic feet per second; $\mathrm{mi}^{2}$, square mile]

\begin{tabular}{clccc}
\hline $\begin{array}{c}\text { Statlon } \\
\text { number }\end{array}$ & $\begin{array}{c}\text { Station on } \\
\text { Mad River }\end{array}$ & $\begin{array}{c}\text { Drainage } \\
\text { area } \\
\left(\mathbf{m l}^{2}\right)\end{array}$ & $\begin{array}{c}\text { Perlod } \\
\text { analyzed } \\
\text { (water } \\
\text { years) }\end{array}$ & $\begin{array}{c}\text { Sustained } \\
\text { ground- } \\
\text { water } \\
\text { clscharge } \\
\text { threshoid } \\
\left(\mathrm{ft}^{3} / \mathrm{s}\right)\end{array}$ \\
\hline 03266500 & At Zanesfield & 731 & $1947-79$ & 0.9 \\
03267000 & Near Urbana & 162 & $1926-31$ & 44 \\
03267900 & At St Paris Pike & 310 & $1966-92$ & $93^{\mathrm{a}}$ \\
03269500 & Near Springfield & 490 & $1915-92$ & 140 \\
03270000 & Near Dayton & 635 & $1916-21$ & 175 \\
& & & $1925-92$ & \\
\hline
\end{tabular}

Threshold determined from duration characteristics adjusted by means of index-station method using station 03269500

The time interval used in the HYSEP prorram is determined empirically as:

$$
\mathrm{I}=2 \mathrm{~A}^{0.2}
$$

where $I$ is the time interval, in days; and $A$ is the drainage area in square miles. The time interval (I) is rounded to the nearest odd integer in the range of 3 to 11.

The assumption that the base-flow recession continues after the time when surface runoff begins is implicit in the local-minimum method. Conseq"ently, base-flow estimates derived by this method ref ect the process of bank storage (Nathan and McMahon. 1990).

HYSEP computes an annual mean base f 'ow for each year analyzed. The median of the annual mean base flows and the median percentage of annual total streamflow attributed to base flow for the five Mad River streamflow-gaging stations are reported in table 2. 
Table 2. Selected base-flow statistics for streamflow-gaging stations on the Mad River, C'io $\left[\mathrm{ft}^{3} / \mathrm{s}\right.$, cubic feet per second; $\left(\mathrm{ft}^{3} / \mathrm{s}\right) / \mathrm{mi}^{2}$, cubic feet per second per square mile; in., inch]

\begin{tabular}{|c|c|c|c|c|c|c|}
\hline \multirow{2}{*}{$\begin{array}{l}\text { Station } \\
\text { number }\end{array}$} & \multirow{2}{*}{$\begin{array}{l}\text { Statlon on } \\
\text { Mad Rlver }\end{array}$} & \multirow{2}{*}{$\begin{array}{l}\text { Perlod } \\
\text { analyzed } \\
\text { (water } \\
\text { years) }\end{array}$} & \multicolumn{3}{|c|}{$\begin{array}{c}\text { Medlan of the annual mean } \\
\text { base flow }\end{array}$} & \multirow{2}{*}{$\begin{array}{c}\text { M:dlan } \\
\text { perrentage } \\
\text { of annual } \\
\text { total } \\
\text { streamflow } \\
\text { d ie to } \\
\text { bare flow }\end{array}$} \\
\hline & & & In. & $\mathrm{ft}^{3} / \mathrm{s}$ & $\frac{\mathrm{ft}^{3}}{\mathbf{m i}^{2} s}$ & \\
\hline 03266500 & At Zanesfield & $1947-79$ & 8.64 & 4.65 & 0.64 & 61.8 \\
\hline 03267000 & Near Urbana & $\begin{array}{l}1926-31 \\
1940-92\end{array}$ & 9.05 & 108 & .66 & 76.1 \\
\hline 03267900 & At St. Paris Pike & $1966-92$ & 10.1 & 231 & .74 & 70.9 \\
\hline 03269500 & Near Springfield & $1915-92$ & 9.26 & 334 & .68 & 68.3 \\
\hline 03270000 & Near Dayton & $\begin{array}{l}1916-21 \\
1925-92\end{array}$ & 9.07 & 424 & .67 & 67.2 \\
\hline
\end{tabular}

\section{Estimation of Sustained Ground-Water- Dlscharge Threshold}

Estimates of an upper limit (or threshold) at which base flow can be considered to be composed predominately of sustained ground-water discharge were made by constructing and analyzing flowduration curves prepared from the daily mean base flow estimates. Before developing the duration curves, an analysis was done to assess the influence of climatic conditions during the analysis period on the computed duration characteristics.

\section{Effects of Analysls-Perlod Climatic Conditions on Flow-Duration Characteristics}

Analysis of streamflow or base-flow data from a wet period generally will result (at least for higher durations) in a larger discharge value for a given percent duration than a more characteristic period would yield. Conversely, analysis of data from a dry period produces the opposite result.

The time periods analyzed for streamflowgaging stations at Zanesfield and St. Paris Pike were significantly shorter than those of the other stations used in this analysis. The climatic represertativeness of these shorter analysis periods with respect to the longer analysis periods of the other stations was assessed by (1) computing the departures of the annual-mean streamflows for the Mad River near Springfield (the station with the longest analysis period) from the mean of the annual-mean streamflows determinad for its analysis period (1915-92 ${ }^{1}$; the reference feriod), and (2) computing the median and mean of th? departures (at the Springfield gaging station) for the shorter analysis periods. Figure 2 shows the annual departures for the reference period at the Springfield gaging station.

The median and mean departure at the Springfield streamflow-gaging station for the period 1947-79 (the analysis period for the Zanesfield gaging station) are -2.8 and 0.7 percent, respectively, of the mean annual-mean discharge. This suggests that streamflow characteristics for the 1947-70 period are, for the purposes of this analysis, representative of the reference period.

\footnotetext{
${ }^{1}$ Unless otherwise designated, time periods re ${ }^{\text {erred }}$ to in this report are in water years.
} 


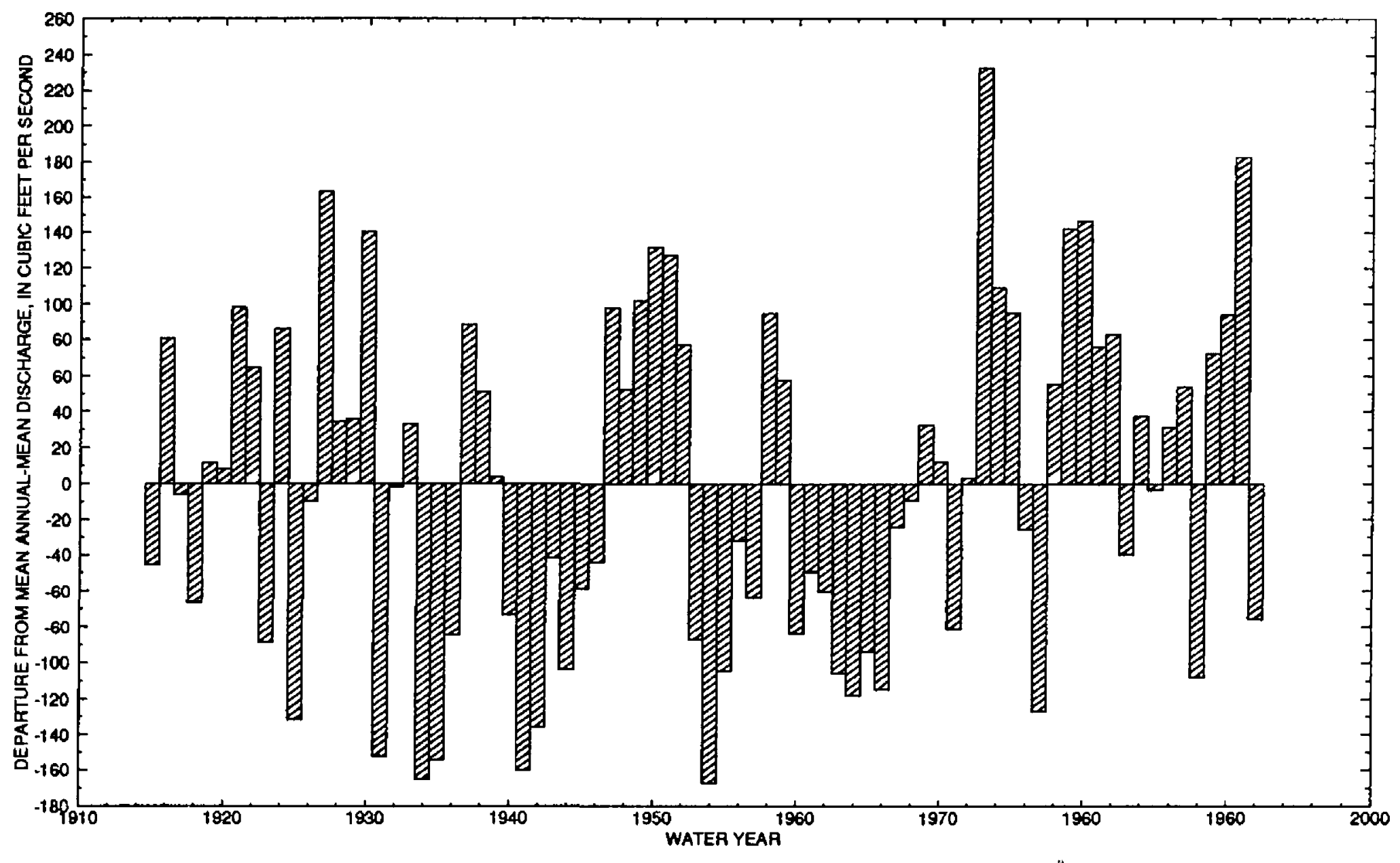

Flgure 2. Annual departure from mean annual-mean discharge for water years 1915-92 at the Mad River near Springfield, Ohio .

The median and mean departure at the Springfield gaging station for the period 1966-92 (the analysis period for the St. Paris Pike gaging station) is 9.8 and 9.5 percent, respectively. This suggests that the 1966-92 period is somewhat wetter than the reference period.

\section{Determination of Flow-Duration Characterlstics}

Flow-duration curves were prepared using methods described by Searcy (1959) as implemented in the USGS program DVSTAT (Dempster,1990). Because the analysis period for the St. Paris Pike gaging station was relatively wet with respect to the reference period, the duration characteristics for that site were adjusted to the reference period by means of the index-station method (Searcy, 1959). The streamflow gaging station near Springfield (03269500) was used as the index station.
Adjustments made by means of the index-station method indicate that unadjusted flow duration characteristics determined for the 1966-92 period are likely to exceed duration characteristics for the reference period by approximately 15 and 30 percert at the 80 and 95 percent durations, respectively.

Plots of streamflow and base-flow duration curves for the five Mad River streamflow-gaging stations are shown in figures 3-7 and selected streamflow and base-flow duration characteristics are listed in tables 3 and 4 . The streamflow and base-flow duration curves generally do not converge (within the limits of the plot) because of a shift in the quantiles of base flow relative to streamflow. This shift is causec by the occasional presence of a surface-runoff component in some very low streamflows. If, for a given site, the class intervals used for streamflow duration analys : differ from those used for the base-flow duration analysis (as they were in this study), then (1) the duration curves may appear to converge, or (2) the gap between the duration curves may be accentuated. 


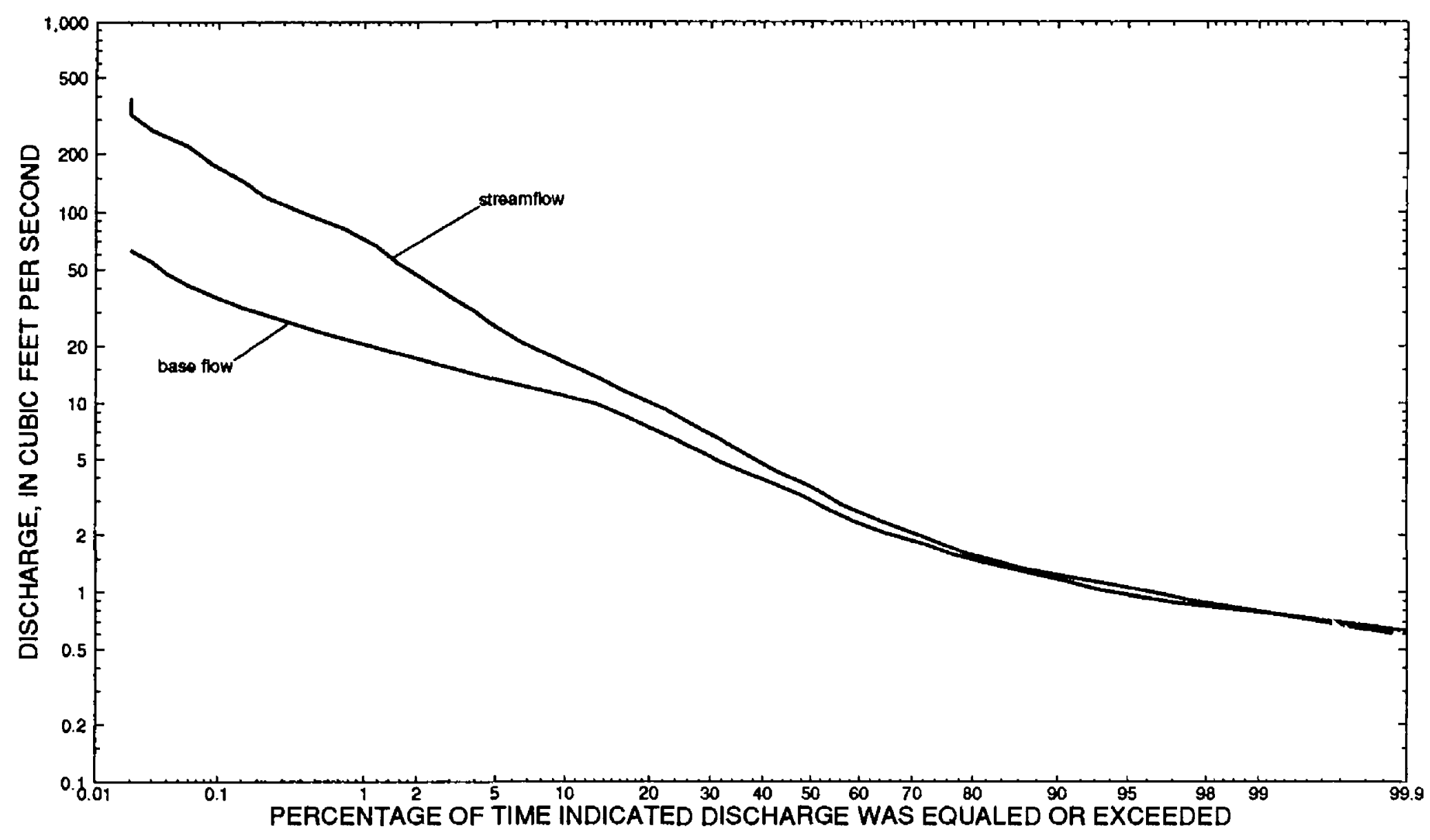

FIgure 3. Streamflow and base-flow duration curves for the Mad River at Zanesfield, Ohio.

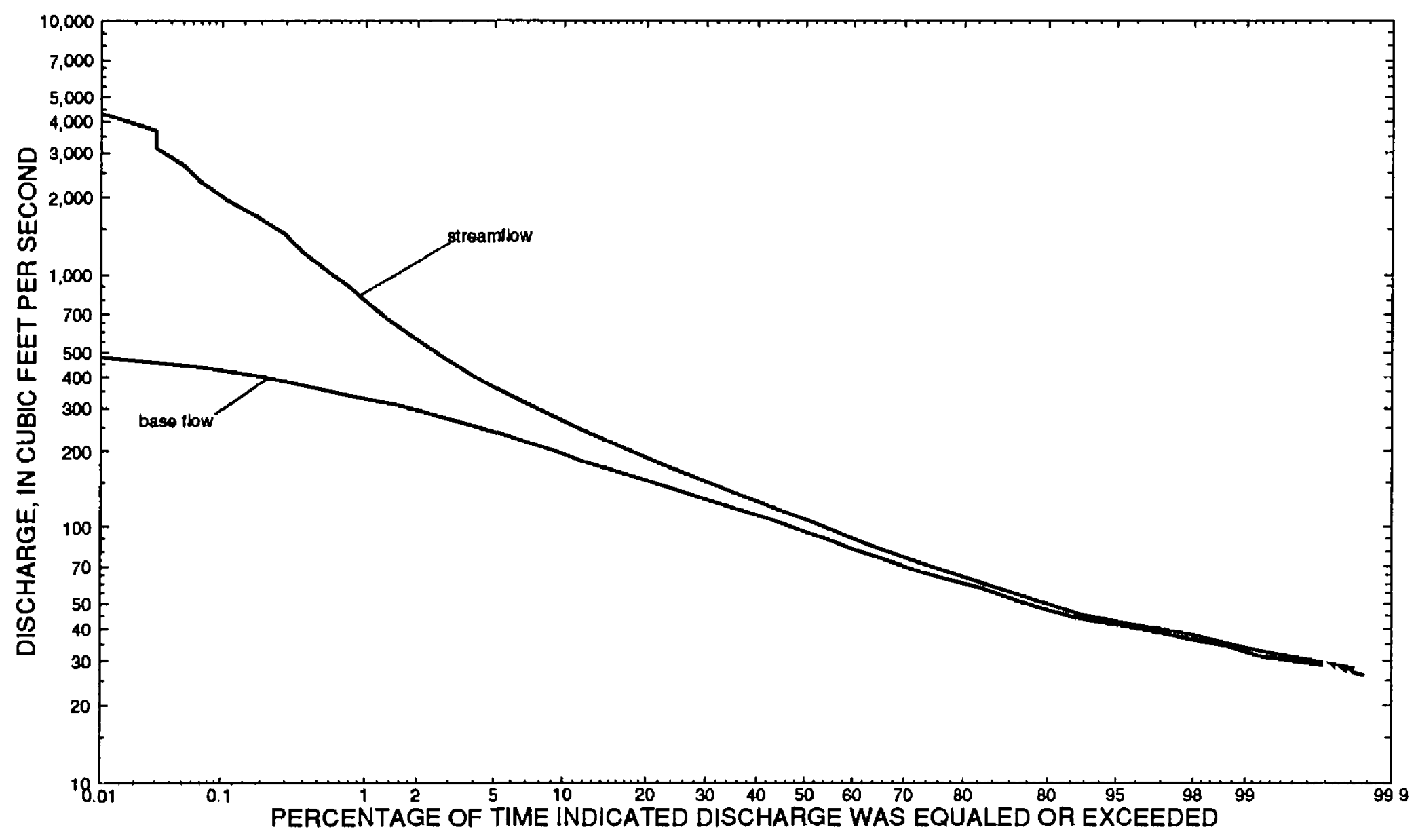

Flgure 4. Streamflow and base-flow duration curves for the Mad River near Urbana, Ohio. 


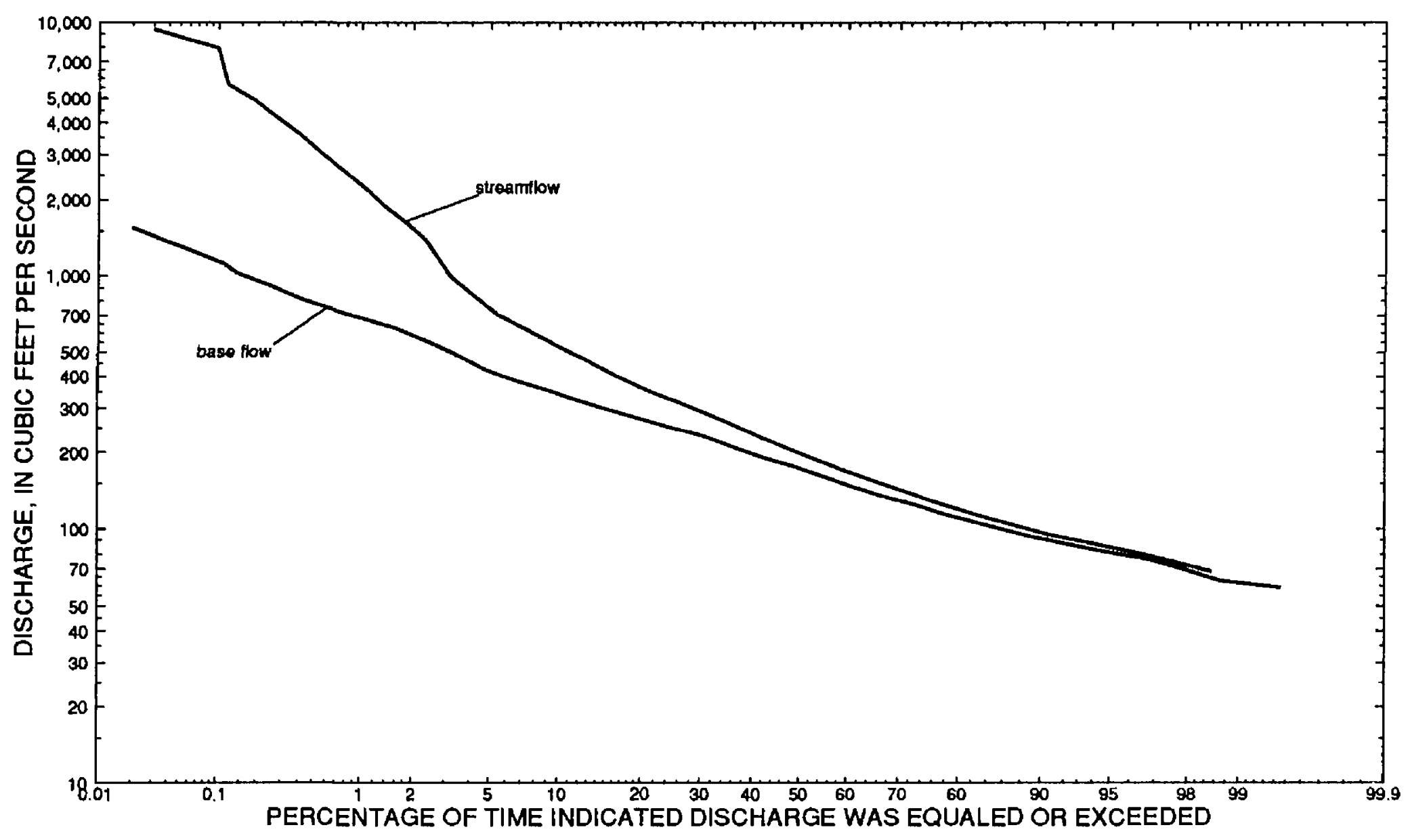

FIgure 5. Streamflow and base-flow duration curves for the Mad River at St. Paris Pike (at Eagle City), Ohio.

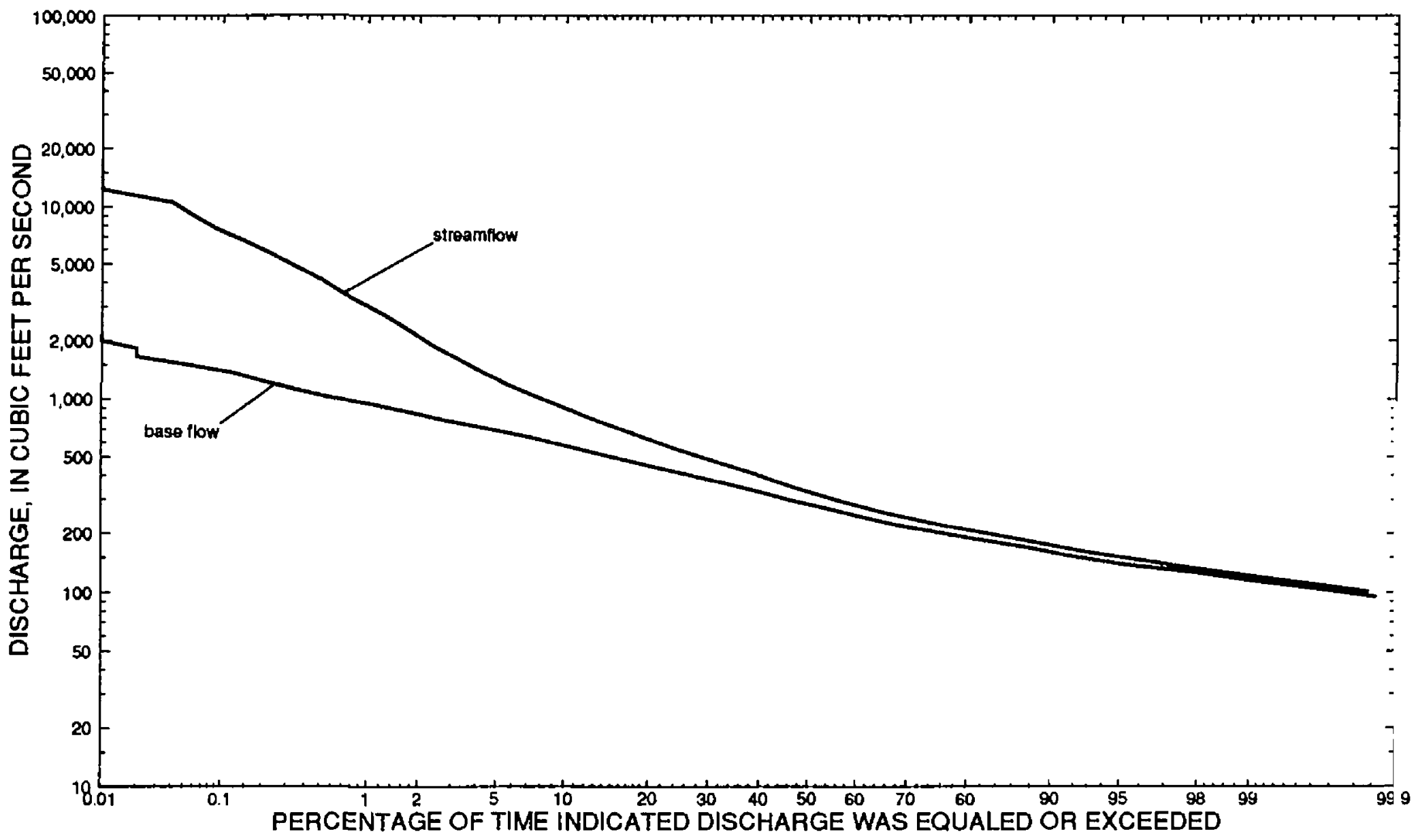

Flgure 6. Streamflow and base-flow duration curves for the Mad River near Springfield, Ohio. 


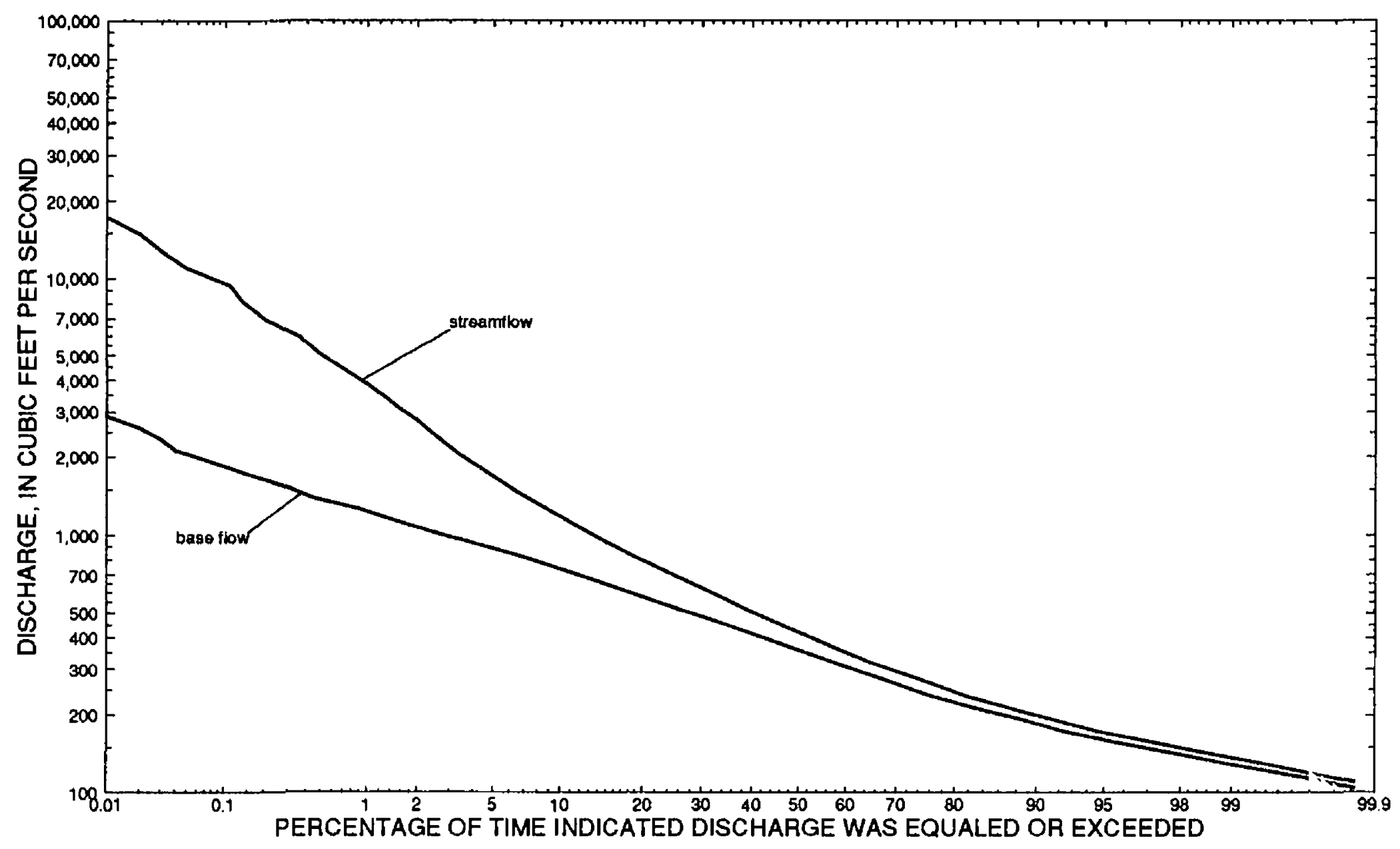

Flgure 7. Streamflow and base-flow duration curves for the Mad River near Dayton, Ohio.

Table 3. Daily streamflow duration characteristics for streamflow-gaging stations on the Mad River, Ohio $\left[\mathrm{ft}^{3} / \mathrm{s}\right.$, cubic feet per second]

\begin{tabular}{cccccccccccccc}
\hline \multirow{2}{*}{$\begin{array}{c}\text { Station } \\
\text { number }\end{array}$} & \multicolumn{1}{c}{ Discharge $\left(\mathbf{f t}^{3} / \mathrm{s}\right)$ that was equaled or exceeded for Indlcated percentage of tIme } \\
\cline { 2 - 13 } & 95 & 90 & 85 & 80 & 75 & 70 & 60 & 50 & 40 & 30 & 20 & 10 \\
\hline 03266500 & 1.0 & 1.2 & 1.4 & 1.6 & 1.8 & 2.0 & 2.6 & 3.6 & 4.8 & 6.8 & 10 & 16 \\
03267000 & 43 & 51 & 58 & 64 & 70 & 77 & 91 & 110 & 130 & 150 & 190 & 270 \\
$03267900^{a}$ & 87 & 97 & 110 & 120 & 130 & 140 & 170 & 210 & 250 & 300 & 360 & 530 \\
03269500 & 150 & 170 & 190 & 210 & 220 & 240 & 280 & 330 & 400 & 490 & 620 & 910 \\
03270000 & 170 & 200 & 220 & 250 & 270 & 300 & 350 & 420 & 510 & 630 & 810 & 1200 \\
\hline
\end{tabular}

${ }^{\mathrm{a} D}$ Duration characteristics adjusted by means of index-station method using station 03269500 
Table 4. Daily base-flow duration characteristics for streamflow-gaging stations on the Mad River, Ohio

$\left[\mathrm{ft}^{3} / \mathrm{s}\right.$, cubic feet per second]

\begin{tabular}{|c|c|c|c|c|c|c|c|c|c|c|c|c|}
\hline \multirow{2}{*}{$\begin{array}{l}\text { Statlon } \\
\text { number }\end{array}$} & \multicolumn{12}{|c|}{ Discharge $\left(\mathrm{ft}^{3} / \mathrm{s}\right)$ that was equaled or exceeded for indlcated percentage of t/me } \\
\hline & 95 & 90 & 85 & 80 & 75 & 70 & 60 & 50 & 40 & 30 & 20 & 10 \\
\hline 03266500 & 1.0 & 1.2 & 1.3 & 1.5 & 1.6 & 1.9 & 2.3 & 3.0 & 3.9 & 5.1 & 7.4 & 11 \\
\hline 03267000 & 42 & 48 & 55 & 61 & 66 & 71 & 83 & 96 & 110 & 130 & 150 & 190 \\
\hline $03267900^{\mathrm{a}}$ & 78 & 88 & 100 & 110 & 120 & 130 & 150 & 180 & 200 & 230 & 270 & 340 \\
\hline 03269500 & 140 & 160 & 180 & 190 & 200 & 220 & 250 & 280 & 330 & 380 & 450 & $\leq 80$ \\
\hline 03270000 & 160 & 190 & 210 & 230 & 240 & 270 & 310 & 360 & 420 & 490 & 580 & 740 \\
\hline
\end{tabular}

${ }^{a}$ Duration characteristics adjusted by means of index-station method using station 03269500

Table 5. Statistics of sustained ground-water discharges for streamflow-gaging stations on the Mad River, Ohio

[ $\mathrm{ft}^{3} / \mathrm{s}$, cubic feet per second; $\left(\mathrm{ft}^{3} / \mathrm{s}\right) / \mathrm{mi}^{2}$, cubic feet per second per square mile]

\begin{tabular}{|c|c|c|c|c|c|c|c|c|c|c|}
\hline \multirow[b]{2}{*}{$\begin{array}{l}\text { Statlon } \\
\text { number }\end{array}$} & \multirow[b]{2}{*}{$\begin{array}{l}\text { Number } \\
\text { of } \\
\text { observa- } \\
\text { tlons }\end{array}$} & \multicolumn{2}{|c|}{ Maximum } & \multicolumn{2}{|c|}{ MInImum } & \multicolumn{2}{|c|}{ Mean } & \multicolumn{3}{|c|}{ Median } \\
\hline & & $\mathrm{ft}^{3} / \mathrm{s}$ & $\frac{\mathrm{ft}^{3}}{\mathrm{mi}^{2} \mathrm{~s}}$ & $\mathrm{ft}^{3} / \mathrm{s}$ & $\frac{\mathrm{ft}^{3}}{\mathrm{mi}^{2} s}$ & $\mathrm{ft}^{3} / \mathrm{s}$ & $\frac{\mathrm{ft}^{3}}{\mathrm{mi}^{2} \mathrm{~s}}$ & $\mathrm{ft}^{3} / \mathrm{s}$ & $\frac{\mathrm{ft}^{3}}{\mathrm{mi}^{2} \mathrm{~s}}$ & $\begin{array}{l}\text { percentexe } \\
\text { of median } \\
\text { annual- } \\
\text { mean base } \\
\text { flow }\end{array}$ \\
\hline 03266500 & 471 & 0.9 & 0.12 & 0.5 & 0.07 & 0.8 & 0.11 & 0.8 & 0.11 & 17.2 \\
\hline 03267000 & 1638 & 44 & .27 & 24 & .15 & 39 & .24 & 40 & .25 & 37.1 \\
\hline 03267900 & 251 & 93 & .30 & 60 & .19 & 82 & .26 & 82 & .26 & 35.6 \\
\hline 03269500 & 1427 & 140 & .29 & 86 & .18 & 125 & .26 & 129 & .26 & 38.6 \\
\hline 03270000 & 2146 & 175 & .28 & 94 & .15 & 152 & .24 & 155 & .24 & 36.6 \\
\hline
\end{tabular}

\section{Selectlon of the Sustalned Ground-Water- Discharge Threshold}

Eberts (in press) suggests that the population of daily mean base flows that form the upper limb of the base-flow-duration curve is composed of an appreciable amount of discharge from local groundwater-flow systems whereas the lower limb population is composed predominately of discharge from deep, stable regional and possibly intermediate ground-water flow systems. Consequently, the point on the baseflow-duration curve where the relatively flat slope of the lower limb changes to the steeper slope of the upper limb was assumed to be the sustained ground-waterdischarge threshold (fig. 8). The sustained groundwater-discharge thresholds, determined visually from the base-flow duration curves, are reported in tatle 1 . The range of sustained ground-water-discharge 


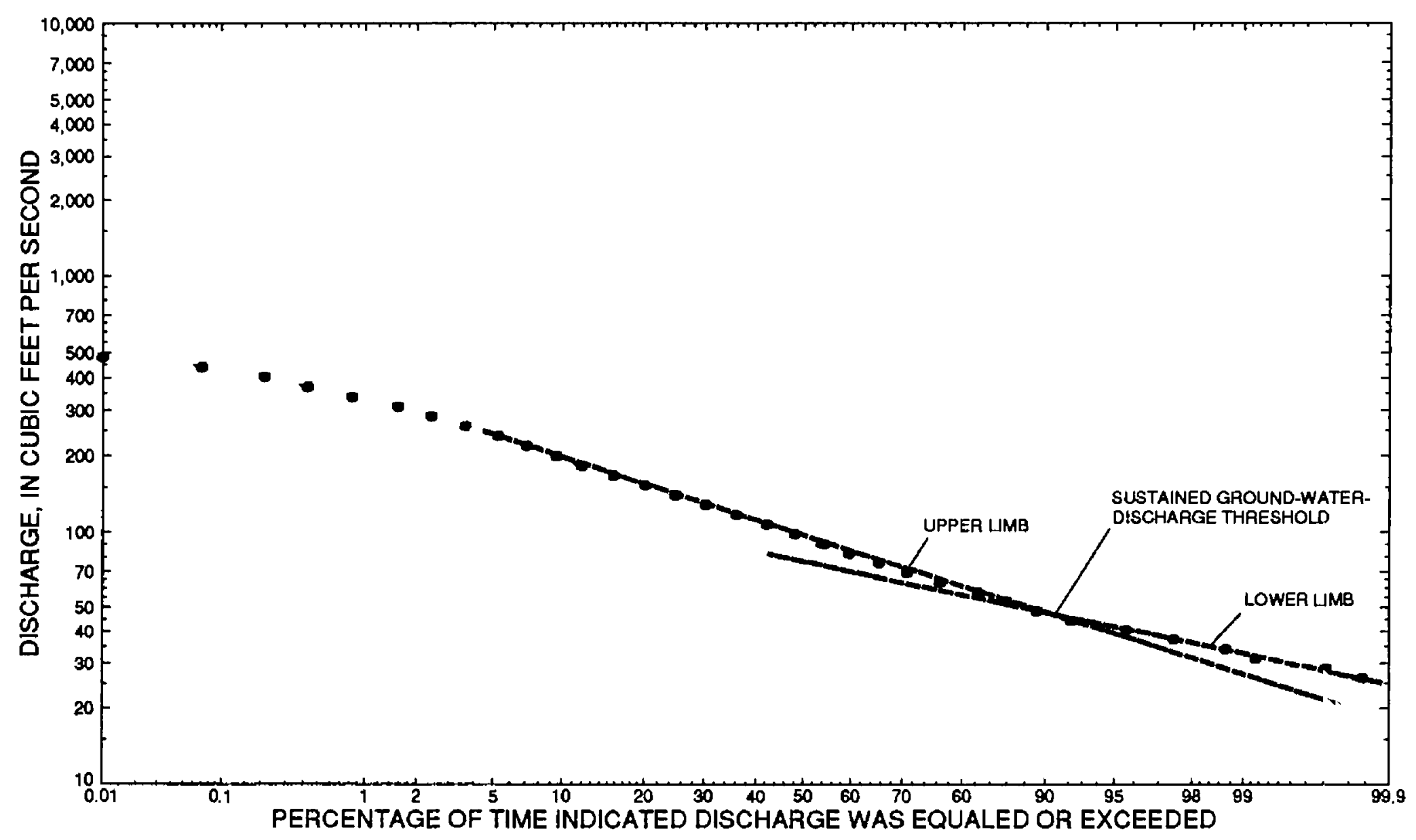

Figure 8. Base-flow duration curve showing selection of sustained ground-water-discharge threshold.

thresholds reported in table 1 corresponds to a range in daily streamflow duration of about 91 to 98 percent.

\section{Statlstics of Sustained Ground-Water Discharge}

The daily mean base-flow time series were filtered to remove values larger than the estimated sustained ground-water-discharge threshold. Those values that passed the filter are considered to be composed predominately of sustained ground-water discharge. Summary statistics of the sustained groundwater-discharge values were determined and are reported in table 5 . The median sustaine ground-water discharge ranged from $0.11\left(\mathrm{ft}^{3} / \mathrm{s}\right) / \mathrm{mi}^{2}$ at Zanesfield to $0.26\left(\mathrm{ft}^{3} / \mathrm{s}\right) / \mathrm{mi}^{2}$ at St. Paris Pike (at Eagle City) and near Springfield. The median sustained ground-water discharge, expressed as a percentage of the median annual-mean base flow, ranged from 17.2 percent at Zanesfield to 38.6 percent near Springfield.

Even very low streamflows can contain a surface-runoff component. Consequently, the daily mean baseflows characterized as sustained groundwater discharge were compared with same-day streamflow values to determine the est mated percentage of sustained ground-water discharge composing the streamflow. Results of that comparison show that 79 to 92 percent of the same-day streamflow values at the five Mad River gaging stations were composed of 85 percent or greater sustained groundwater discharge. In addition, 73 to 86 fercent of the same-day streamflow values were com zosed of 90 percent or greater sustained ground-water discharge (table 6).

\section{Effects of Regulation on Base FInw}

Regulation can affect flow chara:teristics significantly. While some forms of reg llation can affect both high and low flows, only th? effects of regulation on base flow are of concern in this study. Three of the five streamflow-gaging stations listed in table 1 are affected to some degree, by regulation.

Low flows at station 03267900 (Mad River at St. Paris Pike at Eagle City, Ohio) may be affected by pumpage from the Springfield City we'l field, located less than 1 mi upstream, adjacent to the Mad River. Pumpage, averaging $20.2 \mathrm{ft}^{3} / \mathrm{s}$ in 1992 , is returned to 
Table 6. Selected relations between base flows characterized as sustained ground-water discharge and streamflows occurring on the same day $[\%$, percent]

\begin{tabular}{llccc}
\hline Statlon & Station on & $\begin{array}{c}\text { Mean ratio } \\
\text { of } \\
\text { number } \\
\text { sustalned } \\
\text { ground- } \\
\text { water }\end{array}$ & $\begin{array}{c}\text { Percentage of same-day } \\
\text { streamflow values } \\
\text { composed of Indicated } \\
\text { discharge } \\
\text { to }\end{array}$ & $\begin{array}{c}\text { percentage of sustained } \\
\text { ground-water discharge } \\
\text { or greater }\end{array}$ \\
\cline { 5 - 6 } & streamflow & $85 \%$ & $90 \%$ \\
\hline 03266500 & At Zanesfield & 0.96 & 90 & 85 \\
03267000 & Near Urbana & .95 & 92 & 86 \\
03267900 & At St. Paris Pike & .91 & 79 & 73 \\
03269500 & Near Springfield & .91 & 83 & 73 \\
03270000 & Near Dayton & .91 & 86 & 77 \\
\hline
\end{tabular}

the Mad River below the St. Paris Pike gage as treated wastewater.

Studies conducted by Schalk (1992) and R.A. Sheets (U.S. Geological Survey, written commun., 1994) suggest that the City of Dayton's Rohrers' Island well field may affect low flows at station 03270000 (Mad River near Dayton, Ohio). Pumpage from the Rohrers' Island well field averaged $59.6 \mathrm{ft}^{3} / \mathrm{s}$ in 1992.

The C.J. Brown Reservoir, completed on Buck Creek in 1972, provides some regulation of streamflow on the Mad River from the confluence with Buck Creek (3.1 miles downstream from the gage at St. Paris Pike at Eagle City, Ohio) to the mouth.

A double-mass analysis was done to assess whether the potential sources of regulation listed above appreciably affected base flows. Double-mass curves were prepared to compare cumulative base flow at the unregulated Urbana gage with cumulative base flow at the St. Paris Pike, Springfield, and Dayton gages. If appreciable change in regulation affecting base flow had occurred over time, the double-mass curves would reflect that change by changing slope. None of the double-mass curves deviated appreciably from a straight line, suggesting that (1) base-flow regulation resulting from pumpage from the Springfield and
Dayton City well fields is either negligible or has remained fairly constant over the analysis period, and (2) the affect of regulation on base flow, resulting from installation and operation of the C.J. Brown Reservoir, is negligible in the Mad River.

\section{SUMMARY AND CONCLUSIONS}

The hydrograph-separation computer program HYSEP was used to estimate daily and annual-mean base flows for five streamflow-gaging stations on the Mad River. Hydrograph separation was done by means of the local-minimum method because it provided the lowest (most conservative) base-flow estimates of the methods implemented in HYSEP. The median of the annual mean base flows for the five Mad River gaging stations ranged from 0.64 to $0.74\left(\mathrm{ft}^{3} / \mathrm{s}\right) / \mathrm{mi}^{2}$. The median percent of annual total streamflow attribute 1 to base flow ranged from 61.8 to 76.1 percent.

Flow-duration curves prepared from the dail." mean base flows were used to estimate an upper limit, or threshold, at which base flow can be considered to be composed predominately of sustained ground-water discharge. The analysis period for the St. Paris Pike, at Eagle City streamflow-gaging station was found to be 
wet relative to the 1915-92 reference period.

Streamflow and base-flow duration characteristics for the St. Paris Pike station were adjusted to the reference period by means of the index-station method.

The point on the base-flow-duration curve where the relatively flat slope of the lower limb changes to the steeper slope of the upper limb was assumed to be the sustained ground-water-discharge threshold. The sustained ground-water-discharge thresholds ranged from 0.9 to $175 \mathrm{ft}^{3} / \mathrm{s}$ for the five Mad River streamflow-gaging stations.

The estimated base-flow time series for each of the five Mad River gaging stations were filtered to remove values that exceeded their respective sustained ground-water-discharge thresholds. Values that passed the filter were compared with same-day streamflows to determine the estimated percentage of sustained ground-water discharge composing the streamflow. This comparison showed that 79 to 92 percent of sameday streamflows were composed of at least 85 percent sustained ground-water discharge, and 73 to 86 percent of same-day streamflows were composed of at least 90 percent sustained ground-water discharge.

Summary statistics were determined for the sustained ground-water-discharge values. The median (and mean) of the sustained ground-water-discharge values ranged from 0.11 to $0.26\left(\mathrm{ft}^{3} / \mathrm{s}\right) / \mathrm{mi}^{2}$ for the five Mad River gaging stations.

A double-mass analysis was done to assess whether potential regulation by the Springfield and Dayton City well fields and the C.J. Brown Reservoir appreciably affected base flows. This analysis indicated that (1) base flow regulation resulting from pumpage from the Springfield and Dayton City well fields is either negligible or has remained fairly constant over the analysis period, and (2) the affect of regulation on base flow resulting from the installation of the C.J. Brown Reservoir is negligible in the Mad River.

\section{REFERENCES CITED}

Cross, W.P., and Feulner, A.J., 1964, Anomalous streamflow-ground-water regime in the Mad River Basin, near Springfield, Ohio: U.S. Geological Survey Professional Paper, 475-D, p. D198-D201.

Cross, W.P., and Hedges, R.E., 1959, Flow Duration of Ohio Streams: Ohio Department of Natural Resources Bulletin 31, Report No. 3, p.52.

Dempster, G.R., compiler, 1990, National Water information System user's manual, Automated Data Processing
System: U.S. Geological Survey Oren-File Report 90116 , v. 2 , chap 3 [variously paginated].

Eberts, S.M., in press, Ground-water levels and groundwater discharge, glacial-deposits and carbonate-bedrock regional aquifer system, Midvestern Basins and Arches Region: U.S. Geological Survey Hydrologic Atlas, HA-725-E.

Harstine, L.J., 1991, Hydrologic atlas fcr Ohio - average annual precipitation, temperature, streamflow, and water loss for 50-year period, 1931-1980: Ohio Dept. of Natural Resources, Division of Water, Water Inventory Report No. 28,13 p.

Leverett, F., 1902, Glacial formations ard drainage features of the Erie and Ohio basins: U.S. Geological Survey Mono. 41.

Lohman, S.W., and others, 1972, Definitions of selected ground-water terms - Revisions and conceptual refinements: U.S. Geological Survey Water-Supply Paper 1988, p. 2.

Nathan, R.J., and McMahon, T.A., 1990. Evaluation of automated techniques for base flow and recession analyses: Water Resources Research, v. 26, no. 7, 1465$1473 \mathrm{p}$.

Paulson, R.W., Chase, E.B., Roberts, S.F ., and Moody, D.W., compilers, 1991, National Water Summary 1988-89 - Hydrologic events ant floods and droughts: U.S. Geological Survey W/ater-Supply Paper 2375, p. 587.

Pettyjohn, W.A., and Henning, R.J., 1979, Preliminary estimate of ground-water recharge rater. related streamflow and water quality in Ohio: The Ohio State University, Water Resources Center, Project Completion Report 553, $323 \mathrm{p}$.

Rutledge, A.T., 1991, in Regional aquife- systems of the United States - Aquifers of the Southern and Eastern United States: American Water Resources Association, Hotchkiss, W.R. and Johnson, A.I. editors, 59-72 p.

Schalk, C.W., 1992, Ground-water levels and flow in the vicinity of Wright-Patterson Air Force Base, Ohio, October - December 1987: U.S. Geological Survey Water-Resources Investigations Rerort 92-4022, 1 pl.

Searcy, J.K., 1959, Flow-duration curves' U.S. Geological Survey Water-Supply Paper 1542-A. 33 p.

Singh, K.P., 1968, Some factors affecting baseflow: Water Resources Research, v. 4, no. 5, 985-999 p.

Sloto, R.A., 1988, A computer method for estimating ground-water contribution to streamflow using hydrograph-separation techniques: National Computer Technology Meeting, Phoenix, Arizona.

Todd, D.K., 1980, Groundwater hydrolory (2nd ed): New York, Wiley, p. 225.

Tóth, J., 1963, A theoretical analysis of groundwater flow in small drainage basins: Jour. Geophys. Research, v. 68, $4795-4812 \mathrm{p}$. 